\title{
Contribution of genetic variation within SuprMam1 and SuprMam2 to breast cancer susceptibility
}

\author{
M Ratnadiwakara" ${ }^{*}$, M Rooke $^{1}$, R Williams², AC Blackburn \\ From Familial Aspects of Cancer 2011 Research and Practice: A combined meeting of kConFab, Australian \\ Breast Cancer Family Study, Australian Colorectal Cancer Family Study, Australian Ovarian Cancer Study, \\ Family Cancer Clinics of Australia and New Zealand and kConFab \\ Kingscliff, Australia. 23-26 August 2011
}

Two recessive mammary tumour susceptibility loci, SuprMam1 (for suppressor of mammary tumours) on chromosome 7 (110-140 Mb) and SuprMam2 on chromosome $2(120-140 \mathrm{MB})$ have been identified in the BALB/c mouse strain in the Trp53+/- mouse model of spontaneous breast cancer [1]. We studied mammary gland morphology and expression levels of potential candidate genes in SM09 congenic mice (BALB/c SuprMam loci in C57BL/6 background) in comparison to parental strains, to identify the genes within the SuprMam loci that might be responsible for higher cancer susceptibility in BALB/c mice.

We analysed mammary gland wholemounts for differences in their basic morphology. The average of ductal branch count per $4 \mathrm{x}$ field of view was, BALB/c (diestrus) $=171, \mathrm{BALB} / \mathrm{c}$ (estrus) $=173, \mathrm{C} 57 \mathrm{BL} / 6$ (diestrus) $=43$, C57BL $/ 6$ (estrus) $=38$, SM09 (diestrus) $=29$ and SM09 (estrus) $=23$. According to these results, even though there is a significant difference between the numbers of ductal branches between the two parental strains BALB/ $c$ and C57BL/6 (estrus: $p=0.002$, diestrus: $p=0.027$ ), there is no significant difference between congenic (SM09) and control $(\mathrm{C} 57 \mathrm{BL} / 6)$ mice during either estrus $(\mathrm{p}=0.164)$ or diestrus $(\mathrm{p}=0.299)$ stages at 12 months of age. A similar pattern was observed for total epithelial area. This suggests that BALB/c SuprMam alleles alone do not contribute significantly to the morphological differences of the parental strains.

The tumour suppressor DMBT1 (deleted in malignant brain tumors) has previously been identified as a

${ }^{1}$ Molecular Genetics Group, John Curtin School of Medical Research, Australian National University, Canberra ACT 0200, Australia

Full list of author information is available at the end of the article candidate modifier gene within SuprMam1 (1). Using semi-quantitative RT-PCR, Dmbt1 mRNA was found to be significantly lower in mammary glands of susceptible $\mathrm{BALB} / \mathrm{c}$ mice when compared to $\mathrm{C} 57 \mathrm{BL} / 6$, while SM09 congenic mice had similar levels to the control C57BL/6 mice. This indicates that the lower level of Dmbt1 expression in BALB/c mice must be due to transcriptional factor differences outside the region, which is not present in SM09 congenics.

Using Affymetrix data comparing $\mathrm{T}$ cell gene expression across 5 different mouse strains, Cyp2r1, a major vitamin D hydroxylase, was identified as another potential candidate gene in SuprMam1. Plasma 25(OH)D levels were measured in SM09 and control mice to detect the effect of the different Cyp2r1 alleles. The plasma levels of $25(\mathrm{OH}) \mathrm{D}$ were $20 \%$ higher in SM09 mice compared to control mice (control $=49.71 \mathrm{nM} / \mathrm{L}$, $\mathrm{SM} 09=59.44 \mathrm{nM} / \mathrm{L})$. Surprisingly, however, this is the opposite of what is expected based on the association of CYP2R1 expression and cancer susceptibility in human populations.

With these results, we are able to rule out two important candidate genes, DMBT1 and CYP2R1, from being responsible for the higher susceptibility of SuprMam loci. In order to confirm these results, and also to identify the possible involvement of other selected candidate genes, we aim to carry out transcriptional profiling on mammary glands of SM09 congenic and control mice.

\footnotetext{
Author details

${ }^{1}$ Molecular Genetics Group, John Curtin School of Medical Research, Australian National University, Canberra ACT 0200, Australia. ${ }^{2}$ Molecular
} 
Published: 12 April 2012

\section{Reference}

1. Blackburn AC, Hill LZ, Roberts AL, et al: Genetic mapping in mice identifies DMBT1 as a candidate modifier of mammary tumors and breast cancer risk. Am J Pathol 2007, 170:2030-41.

doi:10.1186/1897-4287-10-S2-A90

Cite this article as: Ratnadiwakara et al: Contribution of genetic

variation within SuprMam1 and SuprMam2 to breast cancer

susceptibility. Hereditary Cancer in Clinical Practice 2012 10(Suppl 2):A90.

Submit your next manuscript to BioMed Central and take full advantage of:

- Convenient online submission

- Thorough peer review

- No space constraints or color figure charges

- Immediate publication on acceptance

- Inclusion in PubMed, CAS, Scopus and Google Scholar

- Research which is freely available for redistribution

Submit your manuscript at www.biomedcentral.com/submit 